\title{
The Spectrum Clozaril Clinic model: 12 years of postive outcome findings
}

\author{
Bruce Nisbet ${ }^{1}$, Catherine Dulmus ${ }^{2 *}$, Laura Greyber ${ }^{2}$ \\ From $1^{\text {st }}$ International Congress on Neurobiology and Clinical Psychopharmacology \\ and European Psychiatric Association Conference on Treatment Guidance \\ Thessaloniki, Greece. 19-22 November 2009
}

\section{Background}

Clozaril (generic form Clozapine) is an atypical antipsychotic medication that is appropriate for use with a subset of individuals with psychotic disorders who have not benefited from conventional antipsychotic medications.

\section{Materials and methods}

This poster provides an overview of a unique agencybased integrated outpatient model for treating consumers with Clozaril and reports on 12 years of outcome findings $(n=114)$. These are the outcomes for the first 12 years of the Spectrum Clozaril Clinic for the period of 1993-2005. The "Spectrum Clozaril Clinic" model is built on an interdisciplinary team approach that emphasizes the importance of regular peer interaction, at-site provision of ancillary services, and full coordination by the team of all other treatment, rehabilitation and support services, including specialized case management

\section{Results}

Results indicate that Clozaril delivered within this model promotes an unusually high level of recovery from serious mental illness, including a dramatic level of relief from psychotic symptoms, shielding of suicidal impulses, and reducing inpatient hospitalizations.

\section{Conclusions}

The Spectrum Clozaril Clinic Model is a promising model to promote recovery from serious mental illness.

${ }^{2}$ School of Social Work, University at Buffalo, Buffalo, NY, USA

\section{Author details}

${ }^{1}$ Spectrum Human Services, Orchard Park, NY, USA. ${ }^{2}$ School of Social Work, University at Buffalo, Buffalo, NY, USA.

Published: 22 April 2010

doi:10.1186/1744-859X-9-S1-S155

Cite this article as: Nisbet et al:: The Spectrum Clozaril Clinic model: 12 years of postive outcome findings. Annals of General Psychiatry 2010 9(Suppl 1):S155.
Submit your next manuscript to BioMed Central and take full advantage of:

- Convenient online submission

- Thorough peer review

- No space constraints or color figure charges

- Immediate publication on acceptance

- Inclusion in PubMed, CAS, Scopus and Google Scholar

- Research which is freely available for redistribution

Submit your manuscript at www.biomedcentral.com/submit
C Biomed Central 